\title{
Adaptation Measures of Farmers in Response to Climate Change in Bicol Region, Philippines
}

\author{
Ma. Teresa B. $\operatorname{Lirag}^{1}$, Arthur B. Estrella ${ }^{2}$ \\ ${ }^{1}$ College of Economics and Management, ${ }^{2}$ Graduate School, Central Bicol State University of Agriculture, \\ Pili, Camarines Sur, 4418, Philippines \\ E-mail: materesa.lirag@cbsua.edu.ph,arthurestrella@gmail.com
}

\begin{abstract}
A study was conducted to determine the climate change adaptation (CCA) measures of 211 farmers located in five provinces in the Bicol Region, Philippines. The study employed the descriptive method. A structured questionnaire with open-ended questions served as the main tool for data gathering. Respondents were selected purposively from the Department of Agriculture's master list of farmers. They were selected based on the following criteria: owner of at least one hectare; had been practicing farming for at least five years; a resident of the municipality and living within $50 \mathrm{~km}$ radius of synoptic stations. Frequency counts, weighted means and percentages were used to describe the profile of respondents and their climate change adaptation measures. The major climate hazards the respondents had to contend with are flood, drought, typhoon, erosion and volcanic eruption. Typhoons happen almost every year with varying magnitude. In terms of flood and landslide, residents living in low-lying villages and near river channels, shorelines and mountain slopes are most affected. For the climate-induced drought, the provinces of Albay, Camarines Sur and Catanduanes are more at risk. Volcanic eruptions on the other hand happen in the provinces of Albay and Sorsogon, and hazards brought about by these are volcanic quakes, pyroclastic flow, mudflow, ash fall, landslides, and bush fire. With these climate hazards, farmers practice various CCA measures. Availing of climate forecast services was the most commonly cited and ranked highest across the 4 major hazards, except for erosion where livelihood/income diversification ranked highest as CCA measure. Farmers in the province of Catanduanes had the highest mean score on CCA followed by those in the provinces of Camarines, Sorsogon and Albay. Recommendations include: provision of adequate investment to enhance farmers' access to climate advisories; strengthen nonstructural interventions such as policies, knowledge development, and awareness, to make CCA more effective and reduce the impact of climate change; encourage partnerships between informal processes and formal interventions to facilitate adoption of CCA initiatives introduced by the government; and provide necessary support for the utilization of indigenous knowledge on CCA measures to increase the resiliency of farmers against climate hazards.
\end{abstract}

Keywords - climate hazards; climate change adaptation; natural disaster; risk

\section{INTRODUCTION}

Climate change has become a buzz word in all sectors of the society. Its consequences cannot be underrated in different parts of the world. Numerous studies had been conducted and these all point to its adverse effects on food security and environmental integrity. For instance, an analysis of climate risks for crops in 12 food-insecure regions was conducted to identify adaptation priorities, based on statistical crop models and climate projections for 2030 from 20 general circulation models [1]. Results indicated that South Asia and Southern Africa are two regions that, without sufficient adaptation measures, will likely suffer negative impacts on several crops that are important to large food-insecure human populations.

In 2009, the Food Policy report of the International Food Policy Research Institute also suggested the heightened effect of climate change globally [2]. It reported that in developing countries, climate change will cause yield declines for the most important crops. South Asia will be particularly hard hit. Climate change will have varying effects on irrigated yields across regions, but irrigated yields for all crops in South Asia will experience large declines. Likewise, climate change will result in additional price increases for the most important agricultural crops like rice, wheat, maize, and soybeans. Further, a report stated that most Southeast Asian economies will suffer more welfare losses through deteriorated terms of trade due to climate change and depending on a country's economic structure. The negative effects are expected to be less for Singapore and Malaysia, but greater for Philippines, Indonesia, Thailand, and Vietnam [3]. The United Nations University report also revealed that one of the global hotspots for high disaster risk lies in Southeast Asia where the Philippines ranks third with 26.70 percent world risk index [4]. The 
World Risk Index is calculated with 28 individual indicators and rates the disaster risk for 171 countries in terms of five natural hazards which are earthquakes, cyclones, floods, droughts, and sea-level rise.

This report conforms to that made by the Philippine Atmospheric, Geophysical and Astronomical Services Administration (PAGASA) on climatological data for the past decades [5]. Among PAGASA's key findings were an increase in annual mean temperature by $0.57{ }^{\circ} \mathrm{C}$; increase in maximum and minimum temperatures by $0.35{ }^{\circ} \mathrm{C}$ and $0.94{ }^{\circ} \mathrm{C}$, respectively; significant increase in number of hot days and decrease in the number of cool nights. The result of the analysis of rainfall intensity and frequency are not clear, both in magnitude (by what amounts) and direction (whether increasing or decreasing), with very little spatial coherence.

Indeed, the Philippines is one of the most disaster-prone countries in the world, due to its geographic location and physical environment. On the average, it experiences 20 typhoons annually, which trigger landslides, flash floods, mudslides and widespread flooding, resulting in the destruction of and damage to homes, public infrastructures and agriculture [6]. Likewise, variability in climate caused unprecedented disasters in the country's agriculture sector [7]. Between 2006 and 2013 the government estimates that disasters damaged over 6 million hectares of crops. During this period, the total losses in the agriculture sector were estimated by the government to be US\$3.8 billion, caused by 78 natural disasters. Typhoons and storms caused most of the production losses, amounting to US\$ 3.5 billion or 93 percent. The majority of the losses in the agriculture sector were in the crop sub-sector amounting to US\$ 3.1 billion.

In the Philippines, the Bicol Region is one of the most disaster-prone areas and high-risk environment due to its geophysical location [8,7]. The natural hazards in this region, mainly storms and floods, put the lives of people in vulnerable households at risk. Those who rely predominantly on agriculture are the ones who usually suffer most because it is the sector most vulnerable to natural hazards. In 2006 alone, the loss of investment caused by Typhoon Reming was estimated at US\$16.35 million or Php 817.42 million, not including the lives of more than one thousand individuals [6]. A related report revealed that the total agriculture losses in the Bicol Region between 2006 and 2013 were about US\$260 million, which is 6.8 percent of the country's total losses. Within the same period, typhoons and tropical storms resulted in losses amounting to US\$ 221 million or 85 percent of all agriculture losses in this region [7].

The vulnerability of Bicol region to typhoons and storms is not only because of its geographic location. A study reported that vulnerability is significantly associated with the proportion of rural population, literacy rate and income per capita [9]. Further, long-term climate variability influences sowing date, crop duration, crop yield and the management practices adapted in rice production. Short-term weather episodes can also affect yield by inducing changes in temperature, potential evapotranspiration and moisture availability [10].

At the regional and provincial level, studies on climate change had likewise been conducted. A research study noted that the Camarines Sur province is more vulnerable to drought, which is marked by the occurrence of "much below normal" rainfall conditions, compared to the climate hazards from increased rainfall variability [11]. The effect of drought is highly critical which can put the food security of the province at risk. Seriously considering this negative impact, farmers then must be able to adapt in this changing environment, adjust their cropping calendar and practice sound, climate-smart measures in the farm to minimize the negative effect of climate hazards on crops grown in the region.

The objectives of this research are to determine the climate hazards in the five provinces in Bicol region, identify the CCA measures being practiced by farmers provide management prescriptions to increase the adaptive capacity of farmers against climate hazards

\section{MATERIAL AND METHOD}

The study was carried out in the provinces of Camarines Sur, Camarines Norte, Albay, Sorsogon and Catanduanes in the Bicol Region. Respondents were 211 farmers who were planting rice, corn and coconut. Purposive sampling was used to select from the master list of farmers provided by the Department of Agriculture. The respondents were selected based on the following criteria: owner of at least one hectare; had been practicing farming for a minimum of five years; a resident of the municipality and living within $50 \mathrm{~km}$ radius of synoptic stations. Respondents were from Bula, Tigaon and Goa in Camarines Sur; Ligao and Guinobatan in Albay ; Sorsogon City and Castilla in Sorsogon; Basud and Daet in Camarines Norte; as well as Virac, San Miguel and Bato in Catanduanes. Synoptic stations are in Pili and CBSUA compound in Camarines Sur; Daet and Bagasbas in Camarines Norte; Sorsogon City in Sorsogon; Guinobatan in Albay; and Virac in Catanduanes.

Descriptive method was used in discussing the secondary data gathered on the existing climate hazards and CCA measures in the Bicol Region. A structured questionnaire with open-ended questions served as the main tool for data gathering. Likewise, a focus group discussion elicited more information from the farmers. Document review and data analysis were undertaken to confirm and validate the data gathered from the survey. Frequency counts, weighted means and percentages were used to describe the profile of the respondents and farmers' CCA measures in the field.

\section{RESULTS AND DISCUSSION}

\section{A. The Project Area}

The research study was conducted in the Bicol Region, which is located at the mid-portion of the Philippines. It involved five provinces in the Bicol Region, namely Camarines Sur, Camarines Norte, Albay, Sorsogon, and the island province of Catanduanes (Figure 1). These provinces were selected owing to the presence of synoptic weather station in the area. 


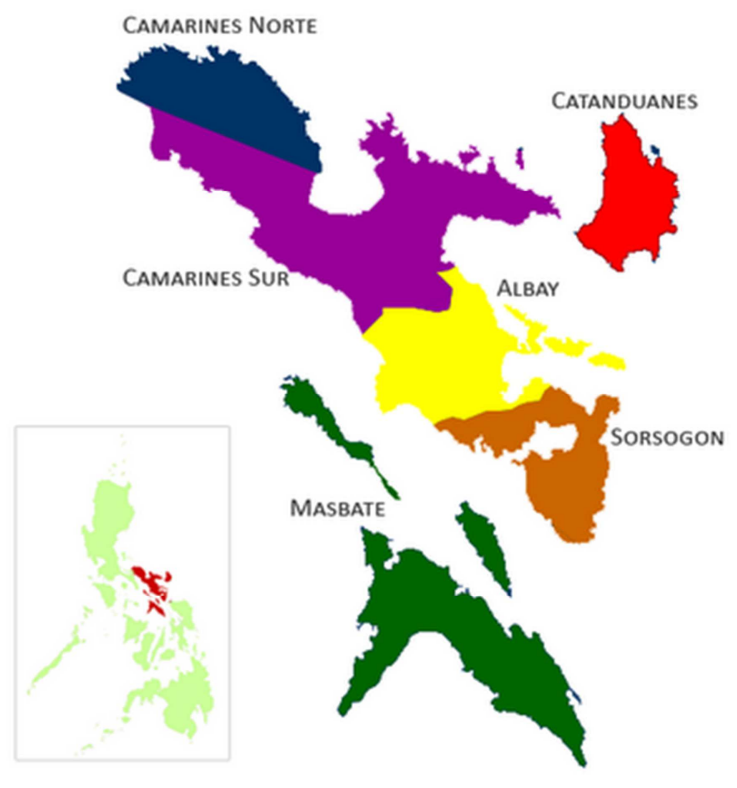

Fig. 1 Map of the Bicol Region, Philippines

\section{B. Socio-demographic Profile of Respondents}

Table 1 presents the socio-demographic profile of respondents. Of the total, a big majority are males (60 percent). The province of Camarines Sur had the highest number of respondents (44 percent) and Sorsogon the least (12 percent). In terms of age, the greatest number of the respondents are 5160 years old (33 percent), 41-50 years old (27 percent) and above 60 years old ( 24 percent). All respondents are involved in farming activities. Aside from farming, the respondents are also involved in other economic activities to augment their income such as working as laborers (33 percent) and engaging in small-scale business ( 30 percent), A big majority of the respondents own the land they till $(65 \%)$, while others are lessees (19 percent) and tenants (16 percent).

\section{The Climate Hazards}

The major climate hazards in the five provinces are flood, drought, typhoon, erosion and volcanic eruption. A research report revealed that the provinces of Albay, Sorsogon and Camarines Sur are included in the top 20 provinces in the Philippines which are at risk of typhoon, rainfall change, drought, and temperature increase [12].

Table 2 shows the strongest typhoons that hit the Bicol Region as published by PAGASA [13]. The list only included the typhoons and their highest wind speeds recorded by PAGASA. There may be other typhoons registering a higher wind speed but were not recorded and/or published by any PAGASA Synoptic, Radar or Automated Weather Station.

The secondary data shows that the strongest typhoons were observed and caused severe destruction in the province of Catanduanes from 1947 to 2014. Other typhoons which had severely affected the Bicol region were the following: typhoons Nina (Nock-ten) in 2016, Lando (Koppu), Nona (Melor) and Amang (Mekkhala) in 2015, Glenda (Rammasun) in 2014 and Pedring (Nesat) in 2011. Focus group discussion with farmer-respondents revealed that strong typhoons in the
Bicol Region happen almost every year although the magnitude or intensity of the typhoon may vary by province.

TABLE I

SOCIO-DEMOGRAPHIC PROFILE of RESPONDENTS

\begin{tabular}{|c|c|c|c|c|c|c|c|}
\hline \multirow[b]{2}{*}{$\begin{array}{l}\text { Varia- } \\
\text { ble }\end{array}$} & \multicolumn{5}{|c|}{ Province } & \multirow[b]{2}{*}{ Total } & \multirow[b]{2}{*}{$\%$} \\
\hline & $\begin{array}{l}\text { Cam } \\
\text { Sur }\end{array}$ & $\begin{array}{l}\text { Cam } \\
\text { Norte }\end{array}$ & $\begin{array}{l}\text { Al } \\
\text { bay }\end{array}$ & $\begin{array}{l}\text { Sor } \\
\text { sogon }\end{array}$ & $\begin{array}{l}\text { Cata } \\
\text { ndua } \\
\text { nes }\end{array}$ & & \\
\hline \multicolumn{8}{|l|}{ Sex } \\
\hline Male & 56 & 13 & 27 & 13 & 18 & 127 & 60 \\
\hline Female & 37 & 19 & 4 & 13 & 11 & 84 & 40 \\
\hline Total & 93 & 32 & 31 & 26 & 29 & 211 & 10 \\
\hline$\%$ & 44 & 15 & 15 & 12 & 14 & 100 & \\
\hline \multicolumn{8}{|l|}{ Age } \\
\hline$>61$ & 22 & 11 & 6 & 4 & 7 & 50 & 24 \\
\hline $51-60$ & 30 & 7 & 14 & 8 & 11 & 70 & 33 \\
\hline $41-50$ & 30 & 6 & 6 & 10 & 6 & 58 & 27 \\
\hline $31-40$ & 7 & 2 & 6 & 9 & 5 & 29 & 14 \\
\hline $21-30$ & 4 & 0 & 0 & 0 & 0 & 4 & 2 \\
\hline Total & 93 & 26 & 32 & 31 & 29 & 211 & \\
\hline \multicolumn{8}{|l|}{$\begin{array}{l}\text { Income } \\
\text { Source } \\
\text { other } \\
\text { than } \\
\text { Farm } \\
\text { ing } \\
\end{array}$} \\
\hline $\begin{array}{l}\begin{array}{l}\text { Entrepr } \\
\text { eneur }\end{array} \\
\end{array}$ & 27 & 8 & 14 & 6 & 8 & 63 & 30 \\
\hline Fishing & 11 & 6 & 5 & 8 & 8 & 38 & 18 \\
\hline Labor & 33 & 9 & 8 & 10 & 9 & 69 & 33 \\
\hline $\begin{array}{l}\text { Employ } \\
\text { ment }\end{array}$ & 22 & 3 & 5 & 7 & 4 & 41 & 19 \\
\hline Total & 93 & 26 & 32 & 31 & 29 & 211 & \\
\hline \multicolumn{8}{|l|}{$\begin{array}{l}\text { Tenu } \\
\text { rial } \\
\text { Status } \\
\end{array}$} \\
\hline Tenant & 17 & 3 & 4 & 5 & 3 & 32 & 16 \\
\hline Lessee & 19 & 5 & 9 & 7 & 1 & 41 & 19 \\
\hline Owner & 57 & 18 & 19 & 19 & 25 & 138 & 65 \\
\hline Total & 93 & 26 & 32 & 31 & 29 & 211 & \\
\hline
\end{tabular}

One of the most adverse impacts of the massive destructions brought about by typhoons is on agricultural production. For instance, in 2015 these typhoons resulted to a 14.61 percent performance decline in corn production (243,908 metric tons) which is lower by about 41,739 metric tons compared to CY 2014, and a reduction in area harvested by 9.31 percent (10.571 hectares). The decline was due to natural calamities brought about by typhoons Amang and Nona, as well as drought [14]. 
TABLE II

STRONGEST TYPHOONS in BICOL REGION, PHILIPPINES (1947-2014)

\begin{tabular}{|c|c|c|c|}
\hline Name & $\begin{array}{ll}\text { Period of } \\
\text { Occurrence }\end{array}$ & $\begin{array}{l}\text { Highest } \\
\text { Wind speed } \\
\text { Recorded }\end{array}$ & Place Observed \\
\hline $\begin{array}{l}\text { Reming } \\
\text { (Durian) }\end{array}$ & $\begin{array}{l}\text { November 26- } \\
\text { Dec 1, } 2006\end{array}$ & $320 \mathrm{kph}$ & $\begin{array}{l}\text { Virac, } \\
\text { Catanduanes }\end{array}$ \\
\hline $\begin{array}{l}\text { Sening+ } \\
\text { (Joan) }\end{array}$ & $\begin{array}{l}\text { October 11-15, } \\
1970\end{array}$ & $275 \mathrm{kph}$ & $\begin{array}{l}\text { Virac, } \\
\text { Catanduanes }\end{array}$ \\
\hline $\begin{array}{l}\text { Rosing } \\
(\text { Angela })\end{array}$ & $\begin{array}{l}\text { October } 30- \\
\text { Nov 4, } 1995\end{array}$ & $260 \mathrm{kph}$ & $\begin{array}{l}\text { Virac, } \\
\text { Catanduanes }\end{array}$ \\
\hline $\begin{array}{l}\text { Anding } \\
\text { (Irma) }\end{array}$ & $\begin{array}{l}\text { November 21- } \\
27,1981\end{array}$ & $260 \mathrm{kph}$ & Daet,Cam Norte \\
\hline $\begin{array}{l}\text { Loleng } \\
(B a b s)\end{array}$ & $\begin{array}{l}\text { October 15-24, } \\
1998\end{array}$ & $250 \mathrm{kph}$ & $\begin{array}{l}\text { Virac, } \\
\text { Catanduanes }\end{array}$ \\
\hline $\begin{array}{l}\text { Sisang } \\
(\text { Nina })\end{array}$ & $\begin{array}{l}\text { November 23- } \\
27,1987\end{array}$ & $240 \mathrm{kph}$ & $\begin{array}{l}\text { Legazpi City, } \\
\text { Albay }\end{array}$ \\
\hline $\begin{array}{l}\text { Saling } \\
(\text { Dot })\end{array}$ & $\begin{array}{l}\text { October 15-20, } \\
1985\end{array}$ & $240 \mathrm{kph}$ & Daet, Cam Norte \\
\hline Harriet & $\begin{array}{l}\text { Dec 28, 1959- } \\
\text { Jan 2, } 1960\end{array}$ & $225 \mathrm{kph}$ & $\begin{array}{l}\text { Virac, } \\
\text { Catanduanes }\end{array}$ \\
\hline Trix & $\begin{array}{l}\text { October 16-23, } \\
1952\end{array}$ & $215 \mathrm{kph}$ & $\begin{array}{l}\text { Legazpi City, } \\
\text { Albay }\end{array}$ \\
\hline $\begin{array}{l}\text { Unsang } \\
\text { (Ruby) }\end{array}$ & $\begin{array}{l}\text { October 21-26, } \\
1988\end{array}$ & $215 \mathrm{kph}$ & $\begin{array}{l}\text { Virac, } \\
\text { Catanduanes }\end{array}$ \\
\hline
\end{tabular}

More than half of the towns in Bicol are prone to flood and landslide based on a report of the Mines and Geosciences Bureau of the Department of Environment and Natural Resources, prompting this agency to warn people living in low-lying villages and near river channels, shorelines and mountain slopes to be extra cautious in the light of extreme rain events [15]. Four out of seven cities and 90 out of 107 municipalities in Bicol are prone to floods and landslides as indicated by the geo-hazard mapping study conducted by the agency. A big majority (79 percent) of the 114 local government units in Bicol are under threat of flood and landslides, while 52 towns as well as the cities of Ligao and Sorsogon are susceptible to high and moderate landslide occurrences, At least 43 towns including the cities of Legazpi and Tabaco in Albay, as well as Naga City in Camarines Sur are flood-prone. In Albay, all 14 towns and three cities of Legazpi, Ligao and Tabaco are vulnerable to flood and landslides. In Camarines Sur, 22 out of 35 municipalities and the city of Naga are prone to flooding and landslides. In Camarines Norte, 8 towns are prone to landslides and 7 are vulnerable to flooding. In Sorsogon, 5 towns and Sorsogon City face the risk of landslides while 11 towns are flood prone. In Catanduanes, all 11 towns in the island province are prone to landslides and flooding.

Aside from the threats of flood and landslide, Bicol also experiences dry condition, dry spell, drought, or El Niño yearly. PAGASA defines drought as three consecutive months of way below normal rainfall (60 percent reduction from average) or five consecutive months of below normal rainfall condition (21-60 percent reduction from average). Dry spell is defined as three consecutive months of below normal rainfall (21-60 percent reduction from average) or two months of consecutive way below normal rainfall (more than 60 percent reduction from average). Dry condition is defined as having two consecutive months of below normal rainfall (2160 percent drop in average rainfall).
In 2016, PAGASA reported that Bicol provinces were at risk of drought starting April 2016. These included Albay, Camarines Sur, and Catanduanes. The country experienced 16- 31 dry days during 2016's first quarter. There were 2631 dry days in March alone across 16 out of 18 regions nationwide. Strong El Niño continued prevailing as data showed sea surface temperature anomaly (SSTA) in the Pacific exceeding $1.5^{\circ} \mathrm{C}$ [16]. In 2015, the dry spell brought about by the El Niño weather phenomenon caused crop losses reaching P58 million in at least 1,040 hectares of agricultural lands in Bicol, mostly in Masbate and Camarines Sur provinces [17]. The production loss in rice, corn and high-value crops for the region reached 3,367.14 metric tons, with a corresponding value of US\$ 1.18 million or Php 58.8 million.

In terms of volcanic eruption, the hazards brought about by this are volcanic quakes, pyroclastic flow, mudflow, ash fall, landslides, and bush fire. Table 3 shows various volcanic activities of Mayon Volcano in Albay [18]. As to Mount Bulusan in Sorsogon, volcanic activities were observed yearly consisting of traces of ash, sulfuric odor and rumbling sound, generation of small pyroclastic flows which cascaded downslopes several kilometers from the summit in some municipalities and villages [19].

TABLE III

VOLCANIC ERUPTION of MAYON VOLCANO, ALBAY

\begin{tabular}{|l|l|l|l|l|}
\hline Hazard & $\begin{array}{l}\text { Scope of } \\
\text { Affected } \\
\text { Areas }\end{array}$ & $\begin{array}{l}\text { Occurrence } \\
\text { per Year } \\
\text { (frequency) }\end{array}$ & $\begin{array}{l}\text { Last Year } \\
\text { of } \\
\text { Occurrence }\end{array}$ & $\begin{array}{l}\text { Return } \\
\text { Period }\end{array}$ \\
\hline $\begin{array}{l}\text { Volcanic } \\
\text { Quakes }\end{array}$ & $\begin{array}{l}3 \text { cities / } 5 \\
\text { munici- } \\
\text { palities }\end{array}$ & $\begin{array}{l}3 \text { cities / } \\
5 \text { munici- } \\
\text { palities }\end{array}$ & 2017 & Daily \\
\hline $\begin{array}{l}\text { Pyroclas- } \\
\text { tic Flow }\end{array}$ & $\begin{array}{l}3 \text { cities / } 5 \\
\text { mun. }\end{array}$ & $\begin{array}{l}3 \text { cities / } \\
5 \text { mun. }\end{array}$ & 2009 & $\begin{array}{l}3-10 \\
\text { yrs. }\end{array}$ \\
\hline Mudflow & $\begin{array}{l}3 \text { cities / 5 } \\
\text { munici- } \\
\text { palities }\end{array}$ & $\begin{array}{l}3 \text { cities / } \\
5 \text { munici- } \\
\text { palities }\end{array}$ & 2017 & Yearly \\
\hline Ash fall & $\begin{array}{l}\text { Province- } \\
\text { wide }\end{array}$ & $\begin{array}{l}\text { Province- } \\
\text { wide }\end{array}$ & 2014 & $\begin{array}{l}3-10 \\
\text { years }\end{array}$ \\
\hline $\begin{array}{l}\text { Land } \\
\text { slides }\end{array}$ & $\begin{array}{l}7 \text { River } \\
\text { channels }\end{array}$ & $\begin{array}{l}7 \text { River } \\
\text { channels }\end{array}$ & 2017 & Yearly \\
\hline Bush Fire & $\begin{array}{l}2 \text { cities/ } \\
3 \text { munici- } \\
\text { palities }\end{array}$ & $\begin{array}{l}2 \text { cities/ munici- } \\
5 \text { malities }\end{array}$ & 2014 & $\begin{array}{l}3-10 \\
\text { yrs. }\end{array}$ \\
\hline
\end{tabular}

\section{Climate Change Adaptation Measures}

Table 4 shows the CCA measures practiced by farmers in each province. Farmer-respondents were asked to rate different CCA measures using a 5 point Likert scale to determine which among these are widely used and most commonly practiced. The various CCA measures were rated from 1.0 to 1.7 (very low); 1.8 to 2.5 (low); 2.6 to 3.3 (moderate); 3.4 to 4.1 (high), and 4.2 to 5.0 (very high) based on the degree of practice as recalled by the farmerrespondent. 
TABLE IV

CLIMATE CHANGE ADAPTATION MEASURES OF FARMERS BY PROVINCE

\begin{tabular}{|c|c|c|c|c|c|c|}
\hline CCA Measures & Mean & $\begin{array}{l}\text { Camarines } \\
\text { Sur } \\
\end{array}$ & Albay & Sorsogon & $\begin{array}{l}\text { Camarines } \\
\text { Norte }\end{array}$ & Catanduanes \\
\hline \multicolumn{7}{|l|}{ A. Flood (La Niña) } \\
\hline 1. Changing planting dates & 2.90 & 3.1 & 1.9 & 2.9 & 2.9 & 3.7 \\
\hline 2. Changing crop duration & 3.00 & 3.3 & 2.0 & 3.0 & 3.5 & 3.2 \\
\hline 3. Changing cropping systems (crop rotation) & 2.70 & 2.9 & 1.7 & 2.4 & 3.1 & 3.4 \\
\hline 4. Using crop varieties which are more disease-resistant & 2.80 & 3.2 & 1.9 & 2.5 & 3.5 & 2.9 \\
\hline 5. Changing planting density & 2.74 & 3.0 & 2.2 & 1.9 & 3.0 & 3.6 \\
\hline 6. Innovative institutional arrangements and policies & 2.42 & 3.1 & 1.0 & 2.2 & 2.8 & 3.0 \\
\hline 7. Livelihood/income diversification & 2.78 & 3.4 & 1.7 & 2.4 & 3.1 & 3.3 \\
\hline 8. Accessing credit & 3.26 & 3.6 & 2.4 & 3.6 & 3.9 & 2.8 \\
\hline 9. Rituals conducted & 2.80 & 3.1 & 1.6 & 3.2 & 3.2 & 2.9 \\
\hline 10. Using crop varieties which are more water-resistant & 3.34 & 3.0 & 3.0 & 3.5 & 3.7 & 3.5 \\
\hline 11. Crop insurance & 3.56 & 3.9 & 3.8 & 3.6 & 3.3 & 3.2 \\
\hline 12. Availing of climate forecasts services (from PAGASA) & 4.00 & 4.0 & 4.2 & 3.9 & 4.1 & 3.8 \\
\hline 13. Change of roles, relationships in the community & 3.60 & 3.8 & 3.5 & 3.7 & 3.4 & 3.6 \\
\hline 14. Accessing savings (other measures) & 3.58 & 3.5 & 3.8 & 3.9 & 3.2 & 3.5 \\
\hline MEAN & 3.12 & 3.4 & 2.5 & 3.1 & 3.3 & 3.3 \\
\hline \multicolumn{7}{|l|}{ B. Drought } \\
\hline 1. Changing planting dates & 2.90 & 3.3 & 2.0 & 2.9 & 3.2 & 3.1 \\
\hline 2. Harvesting and storing rainwater more effectively & 2.78 & 3.1 & 2.2 & 2.4 & 2.9 & 2.9 \\
\hline 3. Agro-biodiversity (agricultural diversification) & 2.36 & 2.4 & 1.5 & 1.6 & 2.7 & 3.6 \\
\hline 4. Changing irrigation methods & 2.74 & 2.9 & 1.9 & 3.0 & 3.1 & 2.8 \\
\hline 5. Using crop varieties which are more resistant to drought & 3.28 & 3.3 & 2.5 & 3.6 & 3.3 & 3.7 \\
\hline 6. Using crop varieties which are more disease-resistant & 2.82 & 2.9 & 1.6 & 2.3 & 3.7 & 3.6 \\
\hline 7. More vigilant protection against fire risks & 2.68 & 3.1 & 1.5 & 1.7 & 3.2 & 3.9 \\
\hline 8. Crop insurance & 2.64 & 3.1 & 1.8 & 2.6 & 2.9 & 2.8 \\
\hline 9. Innovative institutional arrangements and policies & 2.50 & 2.8 & 2.3 & 2.0 & 2.5 & 2.9 \\
\hline 10. Livelihood/income diversification & 2.38 & 2.4 & 1.3 & 2.6 & 2.8 & 2.8 \\
\hline 11. Accessing credit & 2.22 & 2.5 & 1.3 & 2.0 & 2.5 & 2.8 \\
\hline 12. Accessing savings (other measures) & 2.70 & 3.4 & 2.0 & 2.5 & 2.7 & 2.9 \\
\hline 13. Availing of climate forecasts services (from PAGASA) & 3.96 & 3.9 & 3.8 & 4.0 & 4.2 & 3.9 \\
\hline MEAN & 2.78 & 3.0 & 2.0 & 2.6 & 3.1 & 3.2 \\
\hline \multicolumn{7}{|l|}{ C. Typhoon } \\
\hline 1. Changing to less flood-prone or typhoon-prone areas & 2.94 & 3.6 & 2.0 & 2.4 & 3.1 & 3.6 \\
\hline 2. Crop insurance & 3.34 & 3.9 & 2.4 & 3.8 & 3.5 & 3.1 \\
\hline 3. Availing of climate forecasts services (from PAGASA) & 3.44 & 3.8 & 2.2 & 3.2 & 3.8 & 4.2 \\
\hline 4. Livelihood/income diversification & 2.80 & 3.2 & 2.2 & 1.8 & 3.0 & 3.8 \\
\hline 5. Accessing credit & 2.72 & 3.1 & 1.9 & 2.9 & 2.8 & 2.9 \\
\hline 6. Accessing savings (other measures) & 2.38 & 2.8 & 1.3 & 2.1 & 3.0 & 2.7 \\
\hline 7. Rituals conducted & 2.64 & 3.1 & 2.0 & 2.7 & 2.8 & 2.6 \\
\hline MEAN & 2.90 & 3.4 & 2.0 & 2.7 & 3.1 & 3.3 \\
\hline \multicolumn{7}{|l|}{ D. Erosion } \\
\hline 1. Better soil erosion management & 2.62 & 2.7 & 2.7 & 1.7 & 2.9 & 3.1 \\
\hline 2. Crop insurance & 2.66 & 2.8 & 2.8 & 1.6 & 3.1 & 3.0 \\
\hline 3. Livelihood/income diversification & 2.76 & 2.7 & 2.2 & 2.5 & 2.9 & 3.5 \\
\hline 4. Change in roles in the household & 2.68 & 3.1 & 2.2 & 1.6 & 2.8 & 3.7 \\
\hline 5. Accessing credit & 2.70 & 3.2 & 2.1 & 2.5 & 3.0 & 2.9 \\
\hline 6. Accessing savings (other measures) & 2.40 & 2.3 & 1.6 & 1.6 & 3.1 & 3.4 \\
\hline 7. Rituals conducted & 2.68 & 2.4 & 2.5 & 2.8 & 2.9 & 2.8 \\
\hline MEAN & 2.64 & 2.7 & 2.3 & 2.0 & 3.0 & 3.2 \\
\hline \multicolumn{7}{|l|}{ E. Volcanic Eruption } \\
\hline 1. Availing of climate forecasts services (from PAGASA) & 3.36 & 3.1 & 3.9 & 3.6 & 3.2 & 3.0 \\
\hline GRAND MEAN & 2.92 & 3.1 & 2.6 & 2.6 & 3.1 & 3.2 \\
\hline
\end{tabular}




\section{1) Flood}

Data revealed that respondents in the 5 provinces all cited 'availing of climate forecast services from PAGASA' as the most frequent CCA measure for flood (4.0). The CCA with the lowest mean score (2.42) was 'innovative institutional arrangements and policies.' Camarines Sur registered the highest mean score of 3.4 for 'flood hazard' which means that farmers in this province are able to adapt immediately to flood hazard compared to those in the other provinces. This may be explained by the fact that there are more agricultural technicians in Camarines Sur and IEC materials are readily available to farmers whose information-seeking behaviors intensify during climate change hazards. Albay on the other hand, had the lowest mean score (2.5) which may be because most respondents in this province were from the flood-prone municipalities of Polangui and Libon.

This findings conforms to the report that farmers must have the ability to adjust to changes by adapting their farming practices [20]. Adaptation, such as changes in crops and crop varieties, improved water management and irrigation systems, changes in planting schedules and tillage practices, as well as seeking and sharing relevant information, are important in limiting the negative effects and taking advantage of the beneficial effects of changes in climate.

\section{2) Drought}

Availing of climate change forecast services from PAGASA also ranked highest (3.96) as the respondents' CCA measure during droughts, while the lowest ranking CCA measure was accessing credit (2.22). Comparing the five provinces, Catanduanes had the highest drought-related CCA mean score (3.2) with Albay having the lowest mean score (2.0). The high mean for Catanduanes may indicate that most farmers in the province felt more ready at the onset of drought compared to those in the other provinces.

Farmers have been practicing CCA measures previously. A research study reported that to cope with projected climate changes, farmers avail of weather forecasts regularly, change their crop to make the best use of available water, adjust sowing dates according to temperature and rainfall patterns, use crop varieties better suited to new weather conditions (e.g. more resilient to heat and drought), plant hedgerows or small wooded areas on arable land that reduce water run-off and act as wind-breaks [21].

This corroborates findings that market-based instruments such as credits and crop insurance were developed to help poor households in many developing countries cope with the uncertainties in farming [22]. The adoption of such adaptation practices is lagging, but informal institutions play a key role as they rely on enforcement methods not dependent on the government.

\section{3) Typhoon}

Similarly, 'availing of climate forecast services from PAGASA' got the highest mean score (3.44) as the typhoon adaptation measure across five provinces. 'Accessing savings' got the lowest mean score (2.38).

Camarines Sur got the highest mean score (3.4) compared to the other four provinces. This may be due to the presence of additional weather advisories issued by a weather observation center run by a private university in Naga City, Camarines Sur. This weather observation center provides advisories updated every six hours during times of tropical cyclone activity. This allows farmers in the area to rely on this in addition to advisories from PAGASA. Crop insurance as a CCA measure was also given a high score (3.8) by farmerrespondents in the province of Sorsogon. Availing of crop insurance, relocating to less flood-prone or typhoon-prone areas, and livelihood/income diversification received high mean scores of $3.34,2.94$ and 2.80 respectively. Comparing the adaptation measure mean score by province, Camarines Sur and Catanduanes registered the highest with a mean of 3.4 and 3.3, respectively. The lowest is registered in Albay with a mean score of 2.0.

\section{4) Erosion}

Across the five provinces, 'livelihood/income diversification' got the highest mean score (2.76) as a CCA measure for erosion. 'Accessing savings' received the lowest mean score (2.4).

To address the threat of erosion, the CCA measures with highest mean score were more varied per province. Farmer-respondents in Camarines Sur relied on 'accessing credit' and 'change in roles in the household.' In Albay, famer-respondents depended on 'better soil erosion management' and 'crop insurance.' Farmer-respondents in Sorsogon made use of 'livelihood/income diversification,' 'accessing credit,' and 'conducting rituals' adopted from indigenous practices. Camarines Norte farmer-respondents relied on 'crop insurance' and 'accessing savings,' while those in Catanduanes opted to have 'livelihood/income diversification' and 'change in roles in the household' as their adaptation measures.

Catanduanes province received the highest mean score on adaptation measure vis-à-vis erosion as a hazard (3.2) while Sorsogon had the lowest (2.0). The low rating for Sorsogon may be explained by a study on the adaptive capacity of Sorsogon community which was conducted in 2008 [23]. To measure Sorsogon City's adaptive capacity, its socioeconomic, technology and wealth factors were rated using weighted scores on crucial indicators. The indicators used related to the people's capacity to withstand negative effects as well as facilitating factors that allow recovery from the impacts of climate stresses. In the analysis, each indicator was provided a weighted score based on expert judgment of the local government unit's technical staff as to the relevance of each indicator to reconstruction/ rehabilitation and planning/ programming. The nearer the score to 1 , the higher the adaptive capacity. Results showed that Sorsogon City's adaptive capacity was rated lower than the mid-score of 0.5 , signifying low capacity to offset the negative impacts of climate change.

CCA measures vary according to the magnitude of the hazard as experienced in a locality. In 2012, the World Bank pointed out the need to blend adaptation measures in the Philippines into climate-resilient livelihoods for sustainability [24]. Likewise, a study reported that farmers have chosen measures to adapt to the existing climate over a long period of time. For instance, they manage mixed farming of both crops and livestock, adopt an irrigation system, and choose a combination of crops or livestock to maximize their profit, taking the current climate as given [19]. 


\section{5) Volcanic Eruption}

The highest-ranking adaptation measure to mitigate the hazards of volcanic eruption was 'availing climate forecast services from PAGASA' particularly in the provinces of Albay and Sorsogon with mean scores of 3.9 and 3.6, respectively. The presence of Mayon Volcano in Albay and Mount Bulusan in Sorsoogn made the farmer-respondents in these provinces more cautious and keen on CCA. Residents in these provinces tend to be more climate hazard-ready in the event of volcanic eruptions in their area. The provincial government, along with the various City Councils in Albay, created and ordained policies regarding Disaster Risk Reduction and Management (DRRM). Institutions, such as the Center for Initiatives on Research and Climate Action (CIRCA), were established to handle matters of CCA and mitigation. Partnerships with various institutions, such as the PAGASA and the University of the Philippines Los Baños (UPLB) were nurtured [25].

In summary, the climate hazard with the highest mean score on CCA measures was flood (3.12) followed by typhoon (2.90), drought (2.78), erosion (2.64), and volcanic eruption (2.62). Among the provinces, Catanduanes had the highest CCA measure mean score (3.06) followed by the provinces of Camarines Sur (2.98), Camarines Norte (2.94), Sorsogon (2.68), and Albay (2.4).

\section{CONCLUSIONS}

The major climate hazards in the five provinces in the Bicol region are flood, drought, typhoon, erosion and volcanic eruption. Typhoons happen almost every year although the magnitude or intensity of the typhoon vary by province. In terms of flood and landslide, more than half of the towns in Bicol particularly in the provinces of Camarines Sur, Camarines Norte, Albay, Sorsogon, and Catanduanes are prone to these hazards. Residents living in low-lying villages and near river channels, shorelines and mountain slopes are most affected. For drought, the provinces of Albay, Camarines Sur and Catanduanes are more at risk where this weather phenomenon cause crop losses. Volcanic eruption on the other hand, are observed in the provinces of Albay and Sorsogon. Hazards brought about by this are volcanic quakes, pyroclastic flow, mudflow, ash fall, landslides, and bush fire.

To reduce or eliminate the risks to life and property of these climate hazards in the five provinces, the respondents reported practicing various CCA measures. 'Availing of climate forecast services from PAGASA' was most commonly cited and ranked highest across the four major hazards, except for erosion with 'livelihood/income diversification' as top CCA measure. Other CCA measures to mitigate flood as a hazard in agriculture include 'changing of roles,' 'relationships in the community,' 'accessing savings,' 'crop insurance,' 'using crop varieties which were more water resistant,' and 'changing crop duration.'Other CCA measures to mitigate drought as a hazard in agriculture include 'using crop varieties which were more resistant to drought and diseases,' 'changing planting dates,' 'changing irrigation methods,' 'harvesting,' 'storing rainwater more effectively,' and 'accessing savings.' Other CCA measures to mitigate typhoon as a hazard in agriculture include 'crop insurance,' 'changing to less floodprone or typhoon-prone areas,' 'livelihood/income diversification,' and 'accessing credit.' Other CCA measures to mitigate erosion as a hazard in agriculture include 'accessing credit,' 'conduct of rituals,' 'changing of roles in the household,' 'crop insurance,' and 'better soil erosion management.'

With the various CCA measures mentioned, farmerrespondents are able to adjust to changing environment in the five provinces in the Bicol region. The role of PAGASA in providing timely, accurate and reliable weather-related information is very critical to increase the adaptive capacity of farmers against climate hazards thereby ensuring their safety and well-being at all times.

Based on the findings of this study, the following recommendations are prescribed: Provide adequate investment to enhance accessibility of farmers on climate advisories via all forms of media up to the farthest village of the region. This will increase farmers' disaster preparedness and adaptive capacity against major climateinduced hazards.

Strengthen nonstructural interventions such as policies, knowledge development, and awareness, to make CCA more effective and reduce the impact of climate change. This also includes mainstreaming CCA/DRR in agriculture with the active participation of local officials coupled with programs on capacity development.

Encourage partnerships between informal processes and formal interventions to facilitate adaptation of CCA initiatives introduced by the government. Likewise, strategic partnership with local government units, academes, relevant agencies and other stakeholders must be actively pursued.

Provide necessary support for the utilization of indigenous knowledge on CCA adaptation measures to increase the resiliency of farmers against climate hazards.

\section{ACKNOWLEDGMENT}

The authors wish to acknowledge the funding support given by the Commission on Higher Education, Philippines for this project. Likewise, we are grateful for the administrative support of the key officials of the Central Bicol State University of Agriculture in the implementation of this project.

\section{REFERENCES}

[1] David B. Lobell. et al. Prioritizing Climate Change Adaptation Needs for Food Security in 2030. DOI: 10.1126/science.1152339 Science 319, 607 (2008).

[2] Gerald Nelson et al. Climate Change. Impacts on Agriculture and Costs of Adaptation International Food Policy Research Institute. Washington, D.C. October 2009.

[3] F. Zhai and J. Zhuang. 2009. Agricultural Impact of Climate Change: A General Equilibrium Analysis with Special Reference to Southeast Asia. ADBI Working Paper 131. Tokyo: Asian Development Bank Institute. Available: http://www.adbi.org/workingpaper/2009/02/23/2887.

[4] World Risk Report 2016. United Nations University-Institute for Environment and Human Security. United Nations University EHS. Platz der Vereinten Nationen. ISBN 978-3-946785-02-6.

[5] Philippine Atmospheric, Geophysical and Astronomical Services Administration (PAGASA). Climate Change in the Philippines. February 2011.

[6] Arnulfo Mascarinas, et.al. Mainstreaming Disaster Risk Reduction into Agriculture. A case study from Bicol Region, Philippines. Food and Agriculture Organization of the United Nations Rome, 2013 
[7] The Impact of Natural Hazards and Disasters on Agriculture and Food and Nutrition Security. A Call for Action to Build Resilient Livelihoods. FAO of the United Nations. March 2015.

[8] Regional Plan of Action for Disaster Risk Reduction in Agriculture 2014-2018. Bicol Region, Philippines. Department of Agriculture, February 2014.

[9] Michael Cuesta and Roberto F. Ranola Jr.. Adaptive Capacity of Rice Farmers to Rainfall Variability and Extremes in the Province of Camarines Sur, Philippines. Philippine Agricultural Scientist, Vol. 92 No. 4, 419-430. December, 2009.

[10] F.P. Lansigan, W.L. de los Santos and J.O. Coladilla. Agronomic Impacts of Climate Variability on Rice Production in the Philippines. Agriculture, Ecosystems and Environment 82: 129-137. 2000.

[11] Michael A. Cuesta and Roberto F. Ranola Jr. Current Vulnerability of the Rice Production Sector to Rainfall Variability and Extremes in the Province of Camarines Sur, Philippines. J. ISSAS Vol. 14. No.1: 67-79. 2008.

[12] Villarin, Ramon Jose, Vicente, May Celine and Caniete, Ellen Rose Mapping Philippine Vulnerability to Environmental Disasters. Accessed on July 25, 2017 at http://vm.observatory.ph/cw_maps.html

[13] Strongest typhoons in the Philippines. Accessed on July 26, 2017 at http://www.typhoon2000.ph/stormstats/WPF_StrongestTyphoonsPhilip pines_2015Ed.pdf

[14] Department of Agriculture. Accessed on July 26, 2017 at http://bicol.da.gov.ph/index.php/reports-documentation/2137-bicolregion-agricultural-commodity-situationer-2016

[15] Philippine News Agency. Half of Bicol area prone to flooding, landslides. June 27, 2016. Accessed on July 31, 2017 at http://www.thestandard.com.ph/news/-provinces/209174/half-of-bicolarea-prone-to-flooding-landslides.html.

[16] Bicol Standard. Bicol provinces at risk for drought. January 17, 2016. Accessed on July $31, \quad 2017$ at http://www.bicolstandard.com/2016/01/bicol-el-nino-2016.html.
[17] Inquirer Southern Luzon. Michael B. Jaucian - Correspondent Bicol loses P58M worth of crops due to El Niño. September 07, 2015. Accessed on July 31, 2017 at http://newsinfo.inquirer.net/719747/bicol-loses-p58m-worth-ofcrops-due-to-el-nino\#ixzz4oNKFyr6y

[18] APSEMO. Albay Public Safety and Emergency Management Office.

[19] Mount Bulusan. http://www.phivolcs.dost.gov.ph/html/update_VMEPD/vmepd/vme pd/bv_hist.pdf

[20] Cumhur Aydinalp and Cresser, Malcolm. The Effects of Global Climate Change on Agriculture. American-Eurasian J. Agric. \& Environ. Sci., 3 (5): 672-676, 2008 ISSN 1818-6769.

[21] Communication from the Commission to the European Parliament The Council, The European Economic and Social Committee and the Committee of the Regions. An EU Strategy on Adaptation to Climate Change. European Commission, 2013.

[22] [22] C.K. Ranganathan, Palanisami, K. Kakumanu, and A Baulraj. 2010. Mainstreaming the Adaptations and Reducing the Vulnerability of the Poor due to Climate Change. ADBI Working Paper 333. Tokyo: Asian Development Bank Institute. Available: http://www.adbi.org/workingpaper/2011/12/19/4831.adaptations.re ducing.vulnerability.poor.climate.change/

[23] Adelaida Antonette Mias-Mamonong, Yen Flores. Climate Change Assessment for Sorsogon, Philippines: A Summary. HS Number: HS/140/10E. ISBN Number: (Volume) 978-92-1-132255-2. www.unhabitat.org.

[24] The World Bank Group in the Philippines. Policy Note: Climate Change Adaptation in the Philippines: Challenges for CommunityBased Action, 2012.

[25] Salceda, Joey. Agriculture and Development Notes on Climate Change Adaptation. Adaptation Notes. Vol 2. No. 1. 2012. 